\title{
Master Plan for Electricity Distribution Networks Based on Micro- Spatial Projection of Energy Demand
}

\author{
Adri Senen, Christine Widyastuti, Oktaria Handayani \\ Institut Teknologi PLN, Jln.Lingkar Luar Barat Duri Kosambi, Jakarta Barat 11750, Indonesia
}

\begin{tabular}{l} 
ARTICLE INFO \\
\hline Article history: \\
Received November 14, 2021 \\
Revised December 02, 2021 \\
Accepted January 18, 2022 \\
\hline Keywords: \\
Master Plan; \\
Distribution Network; \\
Micro-spatial; \\
Transformer; \\
Distribution Substation
\end{tabular}

Corresponding Author:

Adri Senen, Institut Teknologi PLN, Jln.Lingkar Luar Barat Duri Kosambi, Jakarta Barat 11750, Indonesia. Email: adrisenen@itpln.ac.id

\section{INTRODUCTION}

Electricity demand is increasing due to economic growth and social progress. Higher electricity demand needs to balance the expansion of power plants and infrastructure to support the supply and distribution of electricity from the substation to the consumers [1][2]. Economic growth is followed by the development of growth centers in the cities. It correlates with the shifting and increasing of load centers in urban areas, and thus, it requires a reconfiguration of architecture in medium voltage and low voltage distribution networks, crosschecking substation and distribution substations, and evaluation in direction and orientation of electricity distribution system [3][4].

Direction and orientation of system development are essential in achieving the goal in electricity management. It encompasses consumers' growth forecast and the development concept of primary and secondary distribution networks. There should be a development concept that refers to the characteristics of electricity distribution system design based on the purpose of double role of state electricity enterprise with its aspects of quality, efficiency, and continuity [5][6]. Hence, to set up the targets, a comprehensive master plan is needed. The current master plan of the distribution network has been more simple and easier to implement. However, the results of the projection are still macro-based and unable to show load centers in micro-grids [7][8]. As a consequence, the capacities of the transformers, the numbers of transformers, and the locations of distribution substations cannot be identified accurately [9][10].

For his reason, a micro-spatial-based method in electricity master planning is needed, as it clusters the forecasted areas into grids, it will produce more accurate forecasts and estimate the number of load centers in 
each grid based on the geographical structure [11][12]. Grids-based clustering generates a similarity matrix that provides the level of similarity of a data group. Each grid of the respective cluster is identical and becomes the basis of performance investigation in distribution networks to be applied in master planning [13]. The forecasting results obtained in the form of energy demand projections are then used as an initial reference in designing the distribution network master plan.

The methodology of design characteristics in analyzing the network and the development master plan still refers to the standards set by state electricity supply company such as loading criteria and transformer rating; capacity and layout of distribution substations; area and density of substation services. Furthermore, this is then used as the basic assumption for the derivative characteristics of the medium voltage network. In general, the existing distribution network master plans are still macro and sectoral, so the results tend to be biased for areas experiencing rapid regional development because network planning does not cover the smallest areas [14][15].

Based on this, this paper tries to overcome this problem by accommodating it by dividing the area in the form of grids which are then grouped according to the characteristics of each region, so that it can be seen where the load centers are located, how much and when they occur more accurate. So, the research contribution will produce a master planning of distribution network which help in determining transformer capacity, the placement of substations and distribution substations, evaluation, and orientation of electricity distribution system development. Besides that, a master plan for electricity distribution networks based on micro-spatial will make the development of distribution sub-system can be built accordingly, especially in the area that has dynamic changes in land use due to economic growth affecting their energy demand. So, this research also gives an option to improve the distribution system to increase reliability in certain areas with high, medium, and low-density loads for expanding and upgrading the distribution system.

\section{METHOD}

\subsection{Demand Analysis}

In a system of electricity, it is pivotal to have a strategy of load growth projection and power supply, as electricity demand is increasing due to economic growth and social progress [16][17]. Higher electricity demand needs to balance the expansion of power plants and infrastructure to support the supply and distribution of electricity from the substation to the consumers. The advancement of the electricity system is expected to improve the quality of electricity supply for consumers [18]. This requires a reconfiguration of architecture in medium voltage and low voltage distribution networks, crosschecking substation and distribution substations, and evaluation in direction and orientation of electricity distribution system. Hence, a master plan for electricity system development in the distribution network is needed, which is referred to as the standard quality for distribution system operators. The current master plan method has been more simple and easier to implement. However, the accuracy is apt to be biased, specifically in the area that has limited data and rapid changes in land use due to economic and population growth [19].

\subsection{Method of Master Plan}

The method used in this long-term master plan is focused on several points, explained as follows:

\section{b.1. Micro-spatial load forecasting [20]}

The method used is grid-based and implemented by clustering technique. Here, the grids are clustered into relatively homogenous groups of similar characteristics. Then, the analysis of variables is employed using Principal Component Analysis to generate dominant variables in each group of load growth, which is later used for the calculation of load density [21]. The model of load density is examined by standard statistical technique. The results obtained are projected into loads of future years based on the land use of each grid. The growth of peak load in the district is measured from the peak load density of the district and the size of the area each year during the forecasting period [22]. Load density of the district is obtained from micro-spatial forecasting [23], mathematically written in the following equation:

$$
\hat{P}_{\text {district }}=\hat{\rho}_{\text {district }} A_{\text {district }}
$$

Where $\hat{P}_{\text {district }}$ is load density of the district (MVA/ $\left./ \mathrm{km} 2\right), A_{\text {district }}$ is geographical size area of the district $(\mathrm{km} 2), \hat{\rho}_{\text {district }}$ is peak load of the district (MVA) is how to start another subsection

\section{b.2. Adding transformer substations and new substations}

As the peak load of a Network Area is growing every year, the load of transformer substation also needs to be examined to see whether it is still working along with the standards (a load of transformer substation is designed to normally operate at $60 \%$ and can reach at $80 \%$ for emergency) [24][25]. The additional 
transformers are prioritized for the areas of which the transformer reaches $80 \%$ and the locations selected are the ones in which load density is higher among the districts [26].

b.3. Examining load total of transformers in the district

When transformer load is lower than the standard ( $\leq 80 \%)$, no transformer is added. Meanwhile, when the transformer load is higher than standard $(\geq 80 \%)$, the transformer is added [27].

b.4.Calculating KVA of Transformer

$$
k V A_{\text {addition }}=\left(\frac{M V A_{B P_{k e l}}}{80 \%}-\text { MVAinstalle }\right) 1000
$$

Where kVA addition is a large increase in $\mathrm{kVA}$ in a network, $\mathrm{MVABP} P_{\text {kel }}$ is village peak load and MVA installed is the amount of MVA that has been installed on the network.

b.5. Selecting Rating Capacity of Transformer

The rating capacity of the distribution transformer is selected based on the load density of the district because it can only serve the additional load of the district when the rating capacity of the transformer has a similar or higher load density than the peak load density of the district [28][29].

b.6. The Additional Calculation transformers

$$
\Delta T D=\operatorname{Rundup}\left(\frac{\left(\frac{M V A_{B P_{k e l}}}{80 \%}-M V A_{\text {installed }}\right) 1000}{K V A_{\text {Rating }_{T D}}}\right)
$$

Where $M V A B P_{k e l}$ is village peak load, MVA installed is the amount of MVA that has been installed on the network, and KVA rating TD is a rating of KVA distribution transformer

b.7. Adding distribution substation for each district

$$
R T P G \frac{T D_{A J}}{G D_{A J}}
$$

Where $T D_{A J}$ is Distribution Transformer in Network Area, $G D_{A I}$ is Number of Distribution Substations on the network

To calculate the total of distribution substations added into a district is formulated as the following equation:

$$
\Delta G D_{\text {distrrict }}=\operatorname{Roundup}\left(\frac{T D_{\text {existing }+\Delta T}}{R T P G}\right)-G D_{\text {existing }}
$$

Where $T D_{\text {existing }}$ is Pre-installed distribution transformer, $\triangle T D$ is Number of distribution transformers, $G D_{\text {existing }}$ is the Number of distribution substations that have been installed

Fig. 1 describes the master plan design process for the distribution network, which is based on the projection of energy needs. In general, this research goes through 2 stages, namely the projected stage of energy needs and the distribution network design stage. The research began with the collection of data - data in the form of energy needs, existing conditions such as distribution transformers, distribution substations, transformers in substations, and substations. To project energy needs, micro-spatial is used by dividing clusters of sub-districts that have similar characteristics of regional income, load density, and peak load. This is done to identify different types of loads so that it is easier to map future energy needs. The next step is to design the needs of the distribution network where increasing energy needs will have an impact on the development of the existing electrical network [30].

\section{RESULTS AND DISCUSSION}

The data used in this study is the existing data from the Tangerang Network Area with a total of 119 subdistricts. After the clustering technique was carried out, in this case, cluster I was selected as the cluster sample. The load density data for the transformer installed in Cluster 1 is shown in the following table. From Table 1, it can be seen that from each sub-district, an increase in load density on its network from the first year to the tenth year was found. This shows that there is an increase in the demand for load needs from the community. 


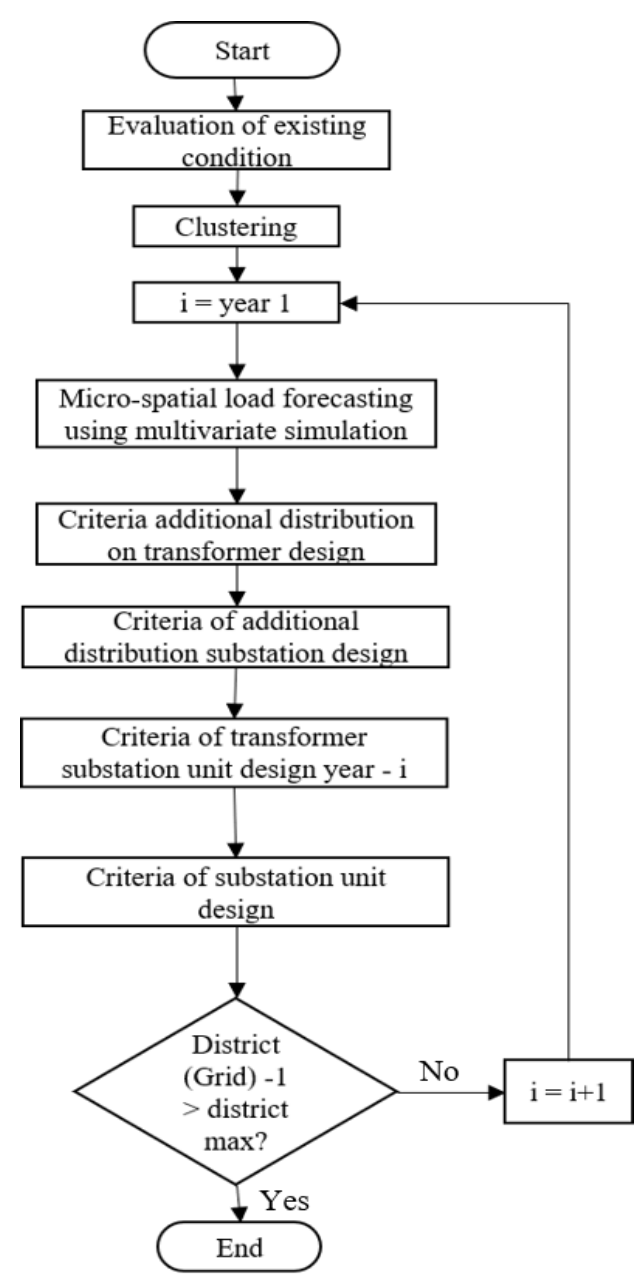

Fig. 1. Research Steps

Table 1. Load Density

No. District Load Density ( MVA/km²)

\begin{tabular}{|c|c|c|c|c|c|c|c|c|c|c|c|}
\hline & & \multicolumn{10}{|c|}{ Year } \\
\hline & & 1 & 2 & 3 & 4 & 5 & 6 & 7 & 8 & 9 & 10 \\
\hline 1 & Legok & 0.5 & 0.524 & 0.558 & 0.596 & 0.641 & 0.693 & 0.752 & 0.82 & 0.899 & 0.99 \\
\hline 2 & Cipondoh & 0.5 & 0.524 & 0.558 & 0.596 & 0.641 & 0.693 & 0.752 & 0.82 & 0.899 & 0.99 \\
\hline 3 & Jatiuwung & 0.32 & 0.335 & 0.358 & 0.384 & 0.414 & 0.45 & 0.492 & 0.541 & 0.599 & 0.667 \\
\hline 4 & Karang Tengah & 0.32 & 0.342 & 0.365 & 0.392 & 0.423 & 0.459 & 0.502 & 0.551 & 0.608 & 0.675 \\
\hline 5 & Pinang & 0.5 & 0.524 & 0.558 & 0.596 & 0.641 & 0.693 & 0.752 & 0.82 & 0.899 & 0.99 \\
\hline 6 & Gembor & 0.32 & 0.342 & 0.365 & 0.392 & 0.423 & 0.459 & 0.502 & 0.551 & 0.608 & 0.675 \\
\hline 7 & Pasir Muncang & 0.5 & 0.524 & 0.558 & 0.596 & 0.641 & 0.693 & 0.752 & 0.82 & 0.899 & 0.99 \\
\hline 8 & Cikupa & 0.5 & 0.524 & 0.558 & 0.596 & 0.641 & 0.693 & 0.752 & 0.82 & 0.899 & 0.99 \\
\hline 9 & Solear & 0.5 & 0.524 & 0.558 & 0.596 & 0.641 & 0.693 & 0.752 & 0.82 & 0.899 & 0.99 \\
\hline 10 & Kresek & 0.5 & 0.524 & 0.558 & 0.596 & 0.641 & 0.693 & 0.752 & 0.82 & 0.899 & 0.99 \\
\hline
\end{tabular}

Apart from the magnitude of the value of the load density on the distribution network, the peak load data on the distribution transformer in each district is also obtained. The increasing load density on the distribution network from each sub-district, it will also affect the peak load of each distribution transformer it serves. The following table shows how much the peak load increase of the distribution transformer from each area it serves from the first year to the tenth year is shown. The existing data of years 1-10 for peak loads of each district in Cluster I are described in Table 2.

Regarding the magnitude of the peak load of the transformer, the need for a KVA transformer must also be adjusted to the peak load of the existing network. With the adjustment between the peak load of the 
transformer and the density of the load on the network, it is necessary to add KVA in each sub-district. The addition of KVA in each sub-district in Cluster I of the Tangerang Network Area for the 1st year to the 10th year is explained in Table 3.

Table 2. Peak Load of District

\begin{tabular}{|c|c|c|c|c|c|c|c|c|c|c|c|}
\hline \multirow[t]{3}{*}{ No } & \multirow[t]{3}{*}{ District } & \multicolumn{10}{|c|}{ Peak Load ( MVA ) District } \\
\hline & & \multicolumn{10}{|c|}{ Year } \\
\hline & & 1 & 2 & 3 & 4 & 5 & 6 & 7 & 8 & 9 & 10 \\
\hline 1 & Legok & 10.6 & 11.2 & 12 & 12.8 & 13.8 & 14.9 & 16.1 & 17.606 & 19.2976 & 21.2457 \\
\hline 2 & Cipondoh & 1.25 & 1.32 & 1.4 & 1.5 & 1.62 & 1.75 & 1.89 & 2.06727 & 2.26589 & 2.49463 \\
\hline 3 & Jatiuwung & 0.35 & 0.37 & 0.39 & 0.42 & 0.46 & 0.49 & 0.54 & 0.59513 & 0.65891 & 0.73409 \\
\hline 4 & Karang Tengah & 0.73 & 0.78 & 0.83 & 0.89 & 0.96 & 1.04 & 1.14 & 1.25117 & 1.38127 & 1.53272 \\
\hline 5 & Pinang & 0.75 & 0.79 & 0.84 & 0.9 & 0.97 & 1.04 & 1.13 & 1.23611 & 1.35488 & 1.49165 \\
\hline 6 & Gembor & 0.98 & 1.04 & 1.11 & 1.19 & 1.28 & 1.39 & 1.52 & 1.67026 & 1.84395 & 2.04612 \\
\hline 7 & Pasir Muncang & 15.8 & 16.7 & 17.8 & 19 & 20.5 & 22.1 & 24 & 26.1793 & 28.6946 & 31.5913 \\
\hline 8 & Cikupa & 9.92 & 10.5 & 11.2 & 12 & 12.9 & 13.9 & 15.1 & 16.4492 & 18.0296 & 19.8497 \\
\hline 9 & Solear & 23.5 & 24.9 & 26.5 & 28.3 & 30.4 & 32.9 & 35.7 & 38.9695 & 42.7136 & 47.0256 \\
\hline 10 & Kresek & 17.8 & 18.8 & 20 & 21.4 & 23 & 24.8 & 27 & 29.4362 & 32.2644 & 35.5215 \\
\hline
\end{tabular}

Table 3. Additional KVA

\begin{tabular}{llllllllrrrrc}
\hline No & \multicolumn{1}{c}{ District } & & & & \multicolumn{7}{c}{ Year } & $\mathbf{9}$ \\
\hline & & $\mathbf{1}$ & $\mathbf{2}$ & $\mathbf{3}$ & $\mathbf{4}$ & $\mathbf{5}$ & $\mathbf{6}$ & $\mathbf{7}$ & $\mathbf{8}$ & $\mathbf{9}$ \\
\hline 1 & Cikupa & 0 & 0 & 0 & 0 & 0 & 0 & $1,070.10$ & $1,535.10$ & $1,760.60$ & $2,035.80$ \\
\hline 2 & Solear & 0 & 0 & 0 & 0 & 0 & 0 & $2,535.00$ & $3,848.20$ & $4,528.30$ & $5,168.30$ \\
\hline 3 & Pasir Muncang & 0 & 0 & 0 & 0 & 0 & 0 & $1,703.00$ & $2,682.60$ & $3,076.70$ & $3,447.60$ \\
\hline 4 & Kresek & 0 & 0 & 0 & 0 & 0 & 0 & $1,914.90$ & $2,984.00$ & $3,519.30$ & $3,840.70$ \\
\hline 5 & Legok & 0 & 0 & 0 & 0 & 0 & 0 & $1,145.30$ & $1,731.00$ & $2,095.40$ & $2,280.60$ \\
\hline 6 & Jatiuwung & 0 & 0 & 0 & 0 & 0 & 0 & 52.7 & 0 & 0.2 & 0 \\
\hline 7 & Cipondoh & 0 & 0 & 0 & 0 & 0 & 0 & 134.5 & 100 & 98.3 & 134.2 \\
\hline 8 & Karang Tengah & 0 & 0 & 0 & 0 & 0 & 0 & 112.8 & 52.5 & 15.2 & 4.5 \\
\hline 9 & Gembor & 0 & 0 & 0 & 0 & 0 & 0 & 150.6 & 137.1 & 154.2 & 206.9 \\
\hline 10 & Pinang & 0 & 0 & 0 & 0 & 0 & 0 & 80.4 & 0 & 107.7 & 28.7 \\
\hline
\end{tabular}

Based on the existing data of additional distribution transformers and distribution substations, each district in Cluster I will have different ratings as they depend on the load density and electricity demands from the respective district. Table 4 shows no additional KVA in Cluster I from year 1 to year 6, which means no transformer is added in the aforementioned years. The absence of additional KVA until the 6th year due to the peak load of the transformer is still at a fairly good (safe) limit. So that no additional transformer was found in that year, as described in Table 4.

Table 4. Additional Transformers and Distribution Substations of Year $1-6$

\begin{tabular}{clcccccc}
\hline No. & \multicolumn{1}{c}{ District } & \multicolumn{2}{c}{ Year -1 } & \multicolumn{3}{c}{ Year -6 } \\
\hline & & Total Rating MVA & Total & (Unit) & Total Rating MVA & Total & (Unit) \\
\hline & & 18 & 29 & 27 & 0 & 0 & 0 \\
\hline 1 & Cikupa & 42 & 70 & 65 & 0 & 0 & 0 \\
\hline 2 & Solear & 28 & 47 & 44 & 0 & 0 & 0 \\
\hline 3 & Pasir Muncang & 32 & 53 & 49 & 0 & 0 & 0 \\
\hline 4 & Kresek & 19 & 31 & 29 & 0 & 0 & 0 \\
\hline 5 & Legok & 1 & 1 & 1 & 0 & 0 & 0 \\
\hline 6 & Jatiuwung & 2 & 4 & 4 & 0 & 0 & 0 \\
\hline 7 & Cipondoh & 1 & 2 & 2 & 0 & 0 & 0 \\
\hline 8 & Karang Tengah & 2 & 3 & 3 & 0 & 0 & 0 \\
\hline 9 & Gembor & 1 & 2 & 2 & 0 & 0 & 0 \\
\hline 10 & Pinang & & & & & 0 & 0 \\
\hline
\end{tabular}


In the 7th to 10th years in Table 5, the number of distribution transformers has increased. This will also affect the length (KMS) of the existing network. So that in the 7th to the 10th year, there is an additional length (KMS) of the distribution network. When distribution transformers are added, as seen in year 7 to year 10 in Cluster I, circuit-kilometer length (KMS) is also extended, as shown in Table 6.

Table 5. Additional Transformers and Distribution Substations of Year 7 - 10

\begin{tabular}{|c|c|c|c|c|c|c|c|c|c|c|c|c|c|}
\hline \multirow[t]{3}{*}{$\begin{array}{l}\mathbf{N} \\
\mathbf{0}\end{array}$} & \multirow[t]{3}{*}{ District } & \multicolumn{3}{|c|}{ Year - 7} & \multicolumn{3}{|c|}{ Year- 8} & \multicolumn{3}{|c|}{ Year-9 } & \multicolumn{3}{|c|}{ Year-10 } \\
\hline & & \multicolumn{2}{|c|}{$\begin{array}{l}\text { Additional Trans- } \\
\text { former }\end{array}$} & \multirow{2}{*}{$\begin{array}{c}\begin{array}{c}\text { Sub- } \\
\text { station }\end{array} \\
\text { (Unit) }\end{array}$} & \multicolumn{2}{|c|}{$\begin{array}{l}\text { Additional Trans- } \\
\text { former }\end{array}$} & \multirow{2}{*}{$\begin{array}{c}\begin{array}{c}\text { Sub- } \\
\text { station }\end{array} \\
\text { (Unit) }\end{array}$} & \multicolumn{2}{|c|}{$\begin{array}{c}\text { Additional } \\
\text { Trans- } \\
\text { former }\end{array}$} & \multirow{2}{*}{$\begin{array}{c}\begin{array}{c}\text { Sub- } \\
\text { sta- } \\
\text { tion }\end{array} \\
\begin{array}{c}\text { (Uni } \\
\text { t) }\end{array}\end{array}$} & \multicolumn{2}{|c|}{$\begin{array}{c}\text { Additional } \\
\text { Trans- } \\
\text { former }\end{array}$} & \multirow{2}{*}{$\begin{array}{c}\begin{array}{c}\text { Sub- } \\
\text { sta- } \\
\text { tion }\end{array} \\
\begin{array}{c}\text { Uni } \\
\text { t) }\end{array}\end{array}$} \\
\hline & & $\begin{array}{c}\text { Rating } \\
\text { kVA }\end{array}$ & Total & & $\begin{array}{c}\text { Rating } \\
\text { kVA }\end{array}$ & Total & & $\underset{\mathbf{k V A}}{\mathbf{g}}$ & $\begin{array}{c}\text { Tot } \\
\text { al }\end{array}$ & & $\underset{\mathbf{k V A}}{\operatorname{Ratin}}$ & $\begin{array}{l}\text { Tot } \\
\text { al }\end{array}$ & \\
\hline 1 & Cikupa & 250 & 5 & 5 & 250 & 7 & 6 & 250 & 8 & 7 & 250 & 9 & 9 \\
\hline 2 & Solear & 250 & 11 & 10 & 250 & 16 & 14 & 250 & 19 & 18 & 250 & 21 & 19 \\
\hline 3 & $\begin{array}{l}\text { Pasir } \\
\text { Mun- } \\
\text { cang }\end{array}$ & 250 & 7 & 6 & 250 & 11 & 10 & 250 & 13 & 12 & 250 & 14 & 13 \\
\hline 4 & Kresek & 250 & 8 & 7 & 250 & 12 & 11 & 250 & 15 & 14 & 250 & 16 & 15 \\
\hline 5 & Legok & 250 & 5 & 4 & 250 & 7 & 7 & 250 & 9 & 8 & 250 & 10 & 9 \\
\hline 6 & $\begin{array}{l}\text { Jatiuwu } \\
\text { ng }\end{array}$ & 200 & 1 & 1 & 0 & 0 & 0 & 200 & 1 & 1 & 0 & 0 & 0 \\
\hline 7 & $\begin{array}{l}\text { Cipon- } \\
\text { doh } \\
\end{array}$ & 250 & 1 & 1 & 250 & 1 & 1 & 250 & 1 & 1 & 250 & 1 & 1 \\
\hline 8 & $\begin{array}{l}\text { Karang } \\
\text { Tengah }\end{array}$ & 200 & 1 & 1 & 200 & 1 & 1 & 200 & 1 & 1 & 250 & 1 & 1 \\
\hline 9 & Gembor & 200 & 1 & 1 & 200 & 1 & 1 & 200 & 1 & 1 & 250 & 1 & 1 \\
\hline 10 & Pinang & 250 & 1 & 1 & 0 & 0 & 0 & 250 & 1 & 1 & 250 & 1 & 1 \\
\hline
\end{tabular}

Table 6. Extension of Circuit-kilometer length (KMS) of Cluster I from year 7 to year 10

\begin{tabular}{llllll}
\hline No. & District & \multicolumn{4}{c}{ Additional kms } \\
\hline & & $\mathbf{7}$ & $\mathbf{8}$ & $\mathbf{9}$ & $\mathbf{1 0}$ \\
\hline 1 & Cikupa & 3.8 & 4.5695 & 5 & 6.9 \\
\hline 2 & Solear & 7.6 & 10.7 & 14 & 14.5 \\
\hline 3 & Pasir Muncang & 4.6 & 7.6 & 9.1 & 9.9 \\
\hline 4 & Kresek & 5.3 & 8.4 & 10.7 & 11.4 \\
\hline 5 & Legok & 3.0 & 5.3 & 6.1 & 6.9 \\
\hline 6 & Jatiuwung & 0.8 & 0.0 & 0.8 & 0.0 \\
\hline 7 & Cipondoh & 0.8 & 0.8 & 0.8 & 0.8 \\
\hline 8 & Karang Tengah & 0.8 & 0.8 & 0.8 & 0.8 \\
\hline 9 & Gembor & 0.8 & 1 & 0.8 & 0.8 \\
\hline 10 & Pinang & 0.8 & 0 & 0.8 & 0.8 \\
\hline
\end{tabular}

As shown from the Table 6, electricity demand from year 1-6 is not high, so the loading capacity of distribution transformers in the area is standard ( $<80 \%$ of the capacity ). The condition of transformer loading is described in Table 7 and Table 8.

\section{CONCLUSION}

Micro-spatial projection of electricity demand can analyze and group the distribution network area of 114 grids into several clusters. This method reduces the process of calculation in the mathematical model to $\mathrm{n}$ Cluster. Projection of energy demand in the form of load density is formulated as transformer rating selection on each distribution substation. Transformer ratings added in each district of the cluster are varied, from 200 $\mathrm{kVA}-250 \mathrm{kVA}$ and $1 \mathrm{MVA}$, and adjusted to the growth of energy demand in the area. The results of the load growth become the basis for determining the capacity and the total of transformers in the area. The projection is used to see the percentages of transformer loadings in each district of the cluster. Finally, the methodology developed in this research has analyzed the transformer rating, transformer capacity, total of transformers, and the location of transformer with growing energy demand in the smaller range. The results can be developed into the design planning of distribution network systems with better accuracy. 
Table 7. Distribution Transformer Loading of Year 1 -Year 5

\begin{tabular}{|c|c|c|c|c|c|c|c|c|c|c|c|}
\hline \multirow[t]{3}{*}{ No } & \multirow[t]{3}{*}{ District } & \multicolumn{10}{|c|}{ Transformer Loading of Year - } \\
\hline & & \multicolumn{2}{|c|}{1} & \multicolumn{2}{|c|}{2} & \multicolumn{2}{|c|}{3} & \multicolumn{2}{|c|}{4} & \multicolumn{2}{|c|}{5} \\
\hline & & $\begin{array}{c}\text { Before } \\
(\%)\end{array}$ & $\begin{array}{c}\text { After } \\
(\%)\end{array}$ & $\begin{array}{c}\text { Before } \\
(\%)\end{array}$ & $\begin{array}{c}\text { After } \\
(\%)\end{array}$ & $\begin{array}{c}\text { Before } \\
(\%)\end{array}$ & $\begin{array}{c}\text { After } \\
(\%)\end{array}$ & $\begin{array}{c}\text { Before } \\
(\%)\end{array}$ & $\begin{array}{l}\text { After } \\
(\%)\end{array}$ & $\begin{array}{c}\text { Before } \\
(\%)\end{array}$ & $\begin{array}{c}\text { After } \\
(\%)\end{array}$ \\
\hline 1 & Cikupa & 55.80 & 55.80 & 59.10 & 59.10 & 62.90 & 62.90 & 67.30 & 67.30 & 72.30 & 72.30 \\
\hline 2 & Solear & 55.80 & 55.80 & 59.10 & 59.10 & 62.90 & 62.90 & 67.30 & 67.30 & 72.30 & 72.30 \\
\hline 4 & Kresek & 55.80 & 55.80 & 59.10 & 59.10 & 62.90 & 62.90 & 67.30 & 67.30 & 72.30 & 72.30 \\
\hline 5 & Legok & 55.80 & 55.80 & 59.10 & 59.10 & 62.90 & 62.90 & 67.30 & 67.30 & 72.30 & 72.30 \\
\hline 6 & Jati Uwung & 55.80 & 55.80 & 59.20 & 59.20 & 63.10 & 63.10 & 67.70 & 67.70 & 73.10 & 73.10 \\
\hline 7 & Cipondoh & 55.80 & 55.80 & 59.10 & 59.10 & 62.90 & 62.90 & 67.30 & 67.30 & 72.30 & 72.30 \\
\hline
\end{tabular}

Table 8. Distribution Transformer Loading of Year 6 -Year 10

\begin{tabular}{|c|c|c|c|c|c|c|c|c|c|c|c|}
\hline \multirow[t]{3}{*}{ No. } & \multirow[t]{3}{*}{ District } & \multicolumn{10}{|c|}{ Transformer Loading of Year - } \\
\hline & & \multicolumn{2}{|c|}{6} & \multicolumn{2}{|c|}{7} & \multicolumn{2}{|c|}{8} & \multicolumn{2}{|c|}{9} & \multicolumn{2}{|l|}{10} \\
\hline & & Before & After & Before & After & Before & After & Before & After & Before & After \\
\hline 1 & Cikupa & $78.10 \%$ & $78.10 \%$ & $84.80 \%$ & $79.20 \%$ & $86.50 \%$ & $79.20 \%$ & $86.80 \%$ & $79.20 \%$ & $87.20 \%$ & $79.30 \%$ \\
\hline 2 & Solear & $78.10 \%$ & $78.10 \%$ & $84.80 \%$ & $79.60 \%$ & $86.90 \%$ & $79.80 \%$ & $87.40 \%$ & $79.70 \%$ & $87.70 \%$ & $79.90 \%$ \\
\hline 3 & Pasir Muncang & $78.10 \%$ & $78.10 \%$ & $84.80 \%$ & $79.60 \%$ & $86.90 \%$ & $79.80 \%$ & $87.40 \%$ & $79.70 \%$ & $87.70 \%$ & $79.90 \%$ \\
\hline 4 & Kresek & $78.10 \%$ & $78.10 \%$ & $84.80 \%$ & $79.80 \%$ & $87.10 \%$ & $80.00 \%$ & $87.60 \%$ & $79.50 \%$ & $87.60 \%$ & $79.70 \%$ \\
\hline 5 & Legok & $78.10 \%$ & $78.10 \%$ & $84.80 \%$ & $79.60 \%$ & $86.80 \%$ & $79.90 \%$ & $87.60 \%$ & $79.50 \%$ & $87.50 \%$ & $79.30 \%$ \\
\hline 6 & Jati Uwung & $79.40 \%$ & $79.40 \%$ & $86.80 \%$ & $65.70 \%$ & $72.30 \%$ & $72.30 \%$ & $80.00 \%$ & $64.40 \%$ & $71.70 \%$ & $71.70 \%$ \\
\hline 7 & Cipondoh & $78.10 \%$ & $78.10 \%$ & $84.80 \%$ & $76.30 \%$ & $83.20 \%$ & $75.60 \%$ & $82.90 \%$ & $75.90 \%$ & $83.60 \%$ & $77.10 \%$ \\
\hline 8 & Karang Tengah & $79.60 \%$ & $79.60 \%$ & $86.90 \%$ & $75.40 \%$ & $82.80 \%$ & $73.10 \%$ & $80.70 \%$ & $72.30 \%$ & $80.20 \%$ & $70.90 \%$ \\
\hline 9 & Gembor & $79.60 \%$ & $79.60 \%$ & $86.90 \%$ & $78.00 \%$ & $85.60 \%$ & $77.70 \%$ & $85.70 \%$ & $78.40 \%$ & $87.00 \%$ & $78.70 \%$ \\
\hline 10 & Pinang & $78.10 \%$ & $78.10 \%$ & $84.80 \%$ & $71.40 \%$ & $77.90 \%$ & $77.90 \%$ & $85.40 \%$ & $73.80 \%$ & $81.30 \%$ & $71.50 \%$ \\
\hline
\end{tabular}

\section{Acknowledgments}

The authors would like to thank the PLN Institute of Technology Jakarta, Indonesia that has supported the process of this research, and the JITEKI team who has allowed us to publish this research paper.

\section{REFERENCES}

[1] S. Zhang, H. Cheng, D. Wang, L. Zhang, F. Li, and L. Yao, "Distributed generation planning in active distribution network considering demand side management and network reconfiguration," Appl. Energy, vol. 228, no. July, pp. 1921-1936, 2018. https://doi.org/10.1016/j.apenergy.2018.07.054

[2] M. Li, D. Allinson, and M. He, "Seasonal variation in household electricity demand: A comparison of monitored and synthetic daily load profiles," Energy Build., vol. 179, pp. 292-300, Nov. 2018. https://doi.org/10.1016/j.enbuild.2018.09.018

[3] M. A. McNeil, N. Karali, and V. Letschert, "Forecasting Indonesia's electricity load through 2030 and peak demand reductions from appliance and lighting efficiency," Energy Sustain. Dev., vol. 49, pp. 65-77, 2019. https://doi.org/10.1016/j.esd.2019.01.001

[4] M. Q. Raza, N. Mithulananthan, J. Li, and K. Y. Lee, "Multivariate Ensemble Forecast Framework for Demand Prediction of Anomalous Days," IEEE Trans. Sustain. Energy, vol. 11, no. 1, pp. 27-36, Jan. 2020. https://doi.org/10.1016/j.esd.2019.01.001

[5] A. Gligor, I. Vlasa, C.-D. Dumitru, C. E. Moldovan, and C. Damian, "Power Demand Forecast for Optimization of the Distribution Costs," Procedia Manuf., vol. 46, pp. 384-390, 2020. https://doi.org/10.1016/j.promfg.2020.03.056

[6] C. Wang et al., "Load Capacity Evaluation of Power Transformer via Temperature Rise Characteristics," in 2020 IEEE Conference on Electrical Insulation and Dielectric Phenomena (CEIDP), 2020, vol. 2020-Octob, pp. 512-515. https://doi.org/10.1109/CEIDP49254.2020.9437520

[7] K. Prakash, F. R. Islam, K. A. Mamun, and H. R. Pota, "Configurations of Aromatic Networks for Power Distribution System," Sustainability, vol. 12, no. 10, p. 4317, May 2020. https://doi.org/10.3390/su12104317

[8] M. Srndovic, A. Zhetessov, T. Alizadeh, Y. L. Familiant, G. Grandi, and A. Ruderman, "Simultaneous Selective Harmonic Elimination and THD Minimization for a Single-Phase Multilevel Inverter With Staircase Modulation," IEEE Trans. Ind. Appl., vol. 54, no. 2, pp. 1532-1541, Mar. 2018. https://doi.org/10.1109/TIA.2017.2775178 
[9] K. Gajowniczek and T. Zabkowski, "Simulation Study on Clustering Approaches for Short-Term Electricity Forecasting," Complexity, vol. 2018, no. iii, 2018. https://doi.org/10.1155/2018/3683969

[10] P. P. Patil, R. K. Patil, and N. Patil, "Dc House: An Alternate Solution for Rural Electrification," Int. J. Trend Sci. Res. Dev., vol. 3, no. 4, pp. 4-7, Jun. 2019. https://doi.org/10.31142/ijtsrd23279

[11] M. Afrasiabi, M. Mohammadi, M. Rastegar, L. Stankovic, S. Afrasiabi, and M. Khazaei, "Deep-Based Conditional Probability Density Function Forecasting of Residential Loads," IEEE Trans. Smart Grid, vol. 11, no. 4, pp. 36463657, Jul. 2020. https://doi.org/10.1109/TSG.2020.2972513

[12] W. Pavón, E. Inga, and S. Simani, "Optimal Routing an Ungrounded Electrical Distribution System Based on Heuristic Method with Micro Grids Integration," Sustainability, vol. 11, no. 6, p. 1607, Mar. 2019. https://doi.org/10.3390/su11061607

[13] S. Abeysinghe, J. Wu, and M. Sooriyabandara, "A Statistical Assessment Tool for Electricity Distribution Networks," Energy Procedia, vol. 105, pp. 2595-2600, 2017. https://doi.org/10.1016/j.egypro.2017.03.747

[14] Q. Xie, J. Xiao, P. Gardoni, and K. Hu, "Probabilistic Analysis of Building Fire Severity Based on Fire Load Density Models," Fire Technol., vol. 55, no. 4, pp. 1349-1375, Jul. 2019. https://doi.org/10.1007/s10694-018-0716-0

[15] A. G. Ismail, M. A. El-Dabah, and I. A. Nassar, "Enhancement of Electrical Distribution Networks Performance Using the Load Management Methodology," Energy Reports, vol. 6, pp. 2066-2074, 2020. https://doi.org/10.1016/j.egyr.2020.07.018

[16] G.-J. Cho, C.-H. Kim, Y.-S. Oh, M.-S. Kim, and J.-S. Kim, "Planning for the Future: Optimization-Based Distribution Planning Strategies for Integrating Distributed Energy Resources," IEEE Power Energy Mag., vol. 16, no. 6, pp. 7787, Nov. 2018. https://doi.org/10.1109/MPE.2018.2864228

[17] G. Parise, L. Parise, L. Martirano, P. Ben Chavdarian, Chun-Lien Su, and A. Ferrante, "Wise Port and Business Energy Management: Port Facilities, Electrical Power Distribution,” IEEE Trans. Ind. Appl., vol. 52, no. 1, pp. 1824, Jan. 2016. https://doi.org/10.1109/TIA.2015.2461176

[18] K. Farahzad, A. Shahbahrami, and M. Ashouri, "Optimal Capacity Determination for Electrical Distribution Transformers Based On IEC 60076-7 And Practical Load Data,” Int. J. Eng. Manuf., vol. 10, no. 1, pp. 1-11, Feb. 2020. https://doi.org/10.5815/ijem.2020.01.01

[19] A. Senen, C. Widyastuti, O. Handayani, and P. Putera, "Development of Micro-Spatial Electricity Load Forecasting Methodology Using Multivariate Analysis for Dynamic Area in Tangerang, Indonesia," Pertanika Journal of Science \& Technology, vol. 29, no. 4, pp. 2565-2578, 2021. https://doi.org/10.47836/pjst.29.4.18

[20] C. Widyastuti, A. Senen, and O. Handayani, "Micro-Spatial Electricity Load Forecasting Using Clustering Technique," Proceeding - 2020 2nd Int. Conf. Ind. Electr. Electron. ICIEE 2020, vol. 11005, pp. 17-21, 2020. https://doi.org/10.1051/e3sconf/202020211005

[21] I. G. M. Y. S. Artha and I. B. G. Manuaba, "Transformer's Load Forecasting to Find the Transformer Usage Capacity with Adaptive Neuro-Fuzzy Inference System Method," J. Electr. Electron. Eng., vol. 7, no. 1, p. 1, 2019. https://doi.org/10.11648/j.jeee.20190701.11

[22] M. Lekshmi and K. N. A. Subramanya, "Short-Term Load Forecasting of 400kV Grid Substation Using R-Tool and Study of Influence of Ambient Temperature on the Forecasted Load," in 2019 Second International Conference on Advanced Computational and Communication Paradigms (ICACCP), 2019, pp. 1-5. https://doi.org/10.1109/ICACCP.2019.8883005

[23] Q. Fu, R. Lai, Y. Shan, and X. Geng, "A Spatial Forecasting Method for Photovoltaic Power Generation Combined of Improved Similar Historical Days and Dynamic Weights Allocation," in 2018 IEEE Innovative Smart Grid Technologies - Asia (ISGT Asia), 2018, pp. 1195-1198. https://doi.org/10.1109/ISGT-Asia.2018.8467889

[24] Q. Hui, T. Haibo, F. Wei, W. Beibei, and W. Qian, "Research on Apache Spark Based Transformer Areas Load Forecasting," in 2018 China International Conference on Electricity Distribution (CICED), 2018, no. 201804260000077, pp. 2437-2441. https://doi.org/10.1109/CICED.2018.8592094

[25] A. Sbravati, M. H. Oka, J. A. Maso, and J. Valmus, "Enhancing Transformers Loadability for Optimizing Assets Utilization and Efficiency," in 2018 IEEE Electrical Insulation Conference (EIC), 2018, no. June, pp. 144-149. https://doi.org/10.1109/EIC.2018.8481063

[26] S. Das and T. Malakar, "A Probabilistic Load Flow with Uncertain Load Using Point Estimate Method," in 2018 15th IEEE India Council International Conference (INDICON), 2018, pp. 1-5. https://doi.org/10.1109/INDICON45594.2018.8987005

[27] M. Djamali, S. Tenbohlen, E. Junge, and M. Konermann, "Real-Time Evaluation of the Dynamic Loading Capability of Indoor Distribution Transformers," IEEE Trans. Power Deliv., vol. 33, no. 3, pp. 1134-1142, Jun. 2018. https://doi.org/10.1109/TPWRD.2017.2728820

[28] S. Bahramara and F. G. Mohammadi, "Optimal sizing of distribution network transformers considering power quality problems of non-linear loads," CIRED - Open Access Proc. J., vol. 2017, no. 1, pp. 2471-2475, Oct. 2017. https://doi.org/10.1049/oap-cired.2017.0258

[29] Y. Tan, H. Chen, W. Liu, M. Zhang, Y. Li, X. Li, and H. Lin, "Repulsive firefly algorithm-based optimal switching device placement in power distribution systems," Glob. Energy Interconnect., vol. 2, no. 6, pp. 489-495, Dec. 2019. https://doi.org/10.1016/j.gloei.2020.01.002

[30] J. Zhang, K. Liu, G. Liu, B. Xu, and Y. Kang, "Research on the Influence of Primary Load Imbalance on the Combined Transformer's Error," in 2018 International Conference on Power System Technology (POWERCON), 2018, no. 201804270000511, pp. 1504-1511. https://doi.org/10.1109/POWERCON.2018.8602069 


\section{BIOGRAPHY OF AUTHORS}

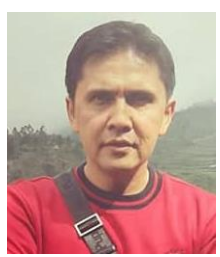

Adri Senen is an electrical engineering lecturer at the faculty of electricity and renewable energy at PLN Institute of Technology. He graduated with electrical engineering Bachelor's degree from Andalas University in 2004 and completed his Magister in School of Electrical and Informatics Engineering, Bandung Institute of Technology in 2008. Email: adrisenen@itpln.ac.id

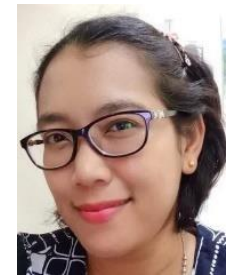

Christine Widyastuti is an electrical engineering lecturer at the faculty of electricity and renewable energy at PLN Institute of Technology. He graduated with electrical engineering Bachelor's degree from PLN Institute of Technology in 2006 and completed his Magister in PLN Institute of Technology in 2015. Email: christine.widyastuti@itpln.ac.id

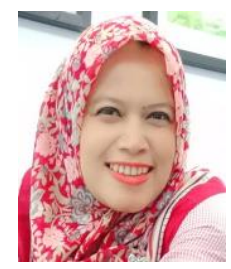

Oktaria Handayani is an electrical engineering lecturer at the faculty of electricity and renewable energy at PLN Institute of Technology. He graduated with electrical engineering Bachelor's degree from PLN Institute of Technology in 2010 and completed his Magister in PLN Institute of Technology in 2015. Email: oktaria@itpln.ac.id 